\title{
PENANGANAN BENDA SITAAN DAN BARANG RAMPASAN NEGARA DI RUMAH PENYIMPANAN BENDA SITAAN NEGARA KELAS I MAKASSAR
}

\author{
Handling of State Confiscated Objects and Seized Goods in State Confiscation House Class I Makassar
}

\author{
Rezky Noor Khadafy ${ }^{1}$, Marwan Mas ${ }^{2}, Z_{\text {Zulkifli Makkawaru }}^{2}$ \\ ${ }^{1}$ Rumah Penyimpanan Benda Sitaan negara Makassar \\ ${ }^{2}$ Program Studi Ilmu Hukum, Program Pascasarjana, Universitas Bosowa \\ Email: rizkybookhadafy@gmail.com
}

Diterima: 08 Januari 2021

Dipublikasikan: 10 Juni 0221

\begin{abstract}
ABSTRAK
Tulisan ini memiliki tujuan agar memahami mengenai tentang penanganan basan atau benda sitaan dan baran atau barang rampasan Negara yang dilaksanakan oleh Rumah Penyimpanan Benda Sitaan Negara ( RUPBASAN) Kelas I Makassar dan mengetahui apa saja yang dialami serta dan mengetahui upaya penyelesaian setiap masalah yang dialami. Penelitian bersifat deskriptif dan merupakan Hukum Empiris. Tempat penelitian dilaksanakan di kantor RUPBASAN kelas I Makassar. Hasil penelitian yang di peroleh dari wawancara pihak RUPBASAN dan pihak kejaksaan sedangkan data pendukung lainnya didapatkan dari bahan pustaka termasuk peraturan yang berlaku yang berkaitan dengan data yang sudah didapatkan pada saat pengumpulan data. Tekhnik analisis data menggunakan model interaktif dengan cara kualitatif menggunakan tiga tahapan yakni tahap mereduksi data, tahap penyajian data dan tahap menarik kesimpulan. Berdasarkan hasil penelitian yang diperoleh dan kemudian dianalisis dapat disimpulkan bahwa langkah-langkah Penanganan basan maupun baran di RUPBASAN Makassar terdiri atas :penerimaan basan/baran, penelitian basan/baran,pendaftaran basan/baran, penyimpanan basan/baran, pemeliharaan basan/baran,pemutasian baran/basan, penyelamatan basan/baran, pengamanan basan/baran, pengeluaran basan/baran, dan penghapusan basan/baran serta pelaporan basan/baran. Selama pelaksanaan Penanganan Benda Sitaan di RUPBASAN Kelas I Makassar masih terdapat masalah yakni tekendala dalam bidang internal maupun bidang eksternal. Sehingga dibutuhkan usaha penanganan kendala tersebut dalam proses Penanganan Benda Sitaan dan Barang Rampasan Negara di Rupbasan Kelas I Makassar.
\end{abstract}

Kata Kunci: Barang Sitaan, Barang Rampasang, RUPBASAN, Efektivitas

\begin{abstract}
This paper aims to understand the handling of state confiscated objects and seized goods carried out by State Confiscation House Class I (RUPBASAN) Makassar and to know what has been experienced and to know the resolution of any problems experienced. This research is descriptive and is an empirical law. This research was conducted in the Office of RUPBASAN Class I Makassar. The results of the research were obtained from interviews with RUPBASAN and the prosecutors while other supporting data were obtained from library materials including applicable regulations relating to the data that was obtained during data collection. The data analysis technique used was an interactive model in a qualitative way using three stages, namely the stage of reducing data, the stage of presenting the data and the stage of drawing conclusions. Based on the results of the research obtained and then analyzed, it can be concluded that the steps for handling confiscated objects and loot in RUPBASAN Makassar consist of: acceptance of confiscated objects and seized goods, research, registration, storage, maintenance, mutation, salvage, protection, removal, and elimination as well as reporting of confiscated objects and seized goods. During the implementation of the Handling of Confiscated Objects at RUPBASAN Class I Makassar there were still problems, such as obstacles from internal and external. Therefore, it takes an effort to handle these obstacles in the process of handling State Confiscated Objects and Seized Goods at RUPBASAN Class I Makassar.
\end{abstract}

Keywords: Confiscated Objects, Seized Goods, RUPBASAN, Effectiveness

\section{PENDAHULUAN}

Negara Indonesia adalah negara hukum,dimana seluruh warga negara diwajibkan mematuhi semua peraturan yang berlaku tanpa terkecuali serta menjunjung tinggi pemerintahan.Jika terjadi permasalahan di lingkungan masyarakat,maka hukum dapat menyelesaikan masalah tersebut.

Kitab Undang-undang Acara Pidana atau disingkat KUHAP memiliki tujuan yakni dapat memberikan perlindungan Hak Asasi manusia(HAM) dan menjamin setiap warga Negara bersama kedudukannya di depan hukum dan pemerintahan serta bersamaan kedudukannya didepan hukum dan pemerintahan. Hal ini berarti KUHAP mengatur dan mengizinkan cara pemaksaan dalam proses penyidikan seperti penangkapan, penahanan, penggeledahan, penyitaan juga pemeriksaan surat. Penyitaan adalah serangkaian tindakan di bawah penguasaannya baik brnda bergerak atau tidak bergerak, berwujud atau tidak berwujud untuk kepentingan pembuktian dan penyidikan, penuntutan, dan peradilan.

KUHAP telah menetapkan tentang lokasi sentral untuk menyimpan basan maupun baran yaitu disimpan di 
dalam Rumah Penyimpanan Benda Sitaan Negara. Rumah Penyimpanan Benda Sitaan Negara ini dikenal dengan nama RUPBASAN, dijelaskan pada pasal 26 Peraturan Pemerintah No.27/1983 tentang pelaksanaan kitab Undang-undang hukum Acara Pidana dan Peraturan Menteri Kehakiman tentang Pengalolaan Benda Sitaan dan Barang Rampasan Negara No: M.05.UM.01.06 Tahun 1983.

Untuk pelaksanaan penanganan basan maupun baran Tentang Petunjuk Pelaksanaan dan Petujuk teknis Pengelolaan Benda Sitaan Negaran dan Barang Rampasan Negara pada Rumah Penyimpanan Benda Sitaan Negara diatur dalam Keputusan Direktur Jendral Pemasyarakatan dengan Nomor : E1.35.PK.03.10 Tahun 2002.

Berdasarkan Peraturan dari Menteri HAM mengenai cara mengelola benda sitaan (basan) maupun barang rampasan (baran) Nomor 16 Tahun 2014 pada Pasal 19.

Ayat (1): Kepala RUPBASAN wajib Melakukan Pemeliharaan Terhadap fisik Badan dan Baran secara berkala serta di catat dalam buku pemeliharaan ,

Ayat (2): Standar Pemeliharaan dilakukan sesuaidengan standar yang ditetapkan Direktur Jenderal Pemasyarakatan.

Dalam pemeriksaan proses hukum Pidana tidak sedikit penyidik terpaksa melakukan penyitaan benda sitaan maupun barang rampasan sebagai alat bukti kejahatan tersangka. Beberapa kasus pidana yang sedang dalam proses penyidikan sering dijumpai benda sitaan atau barang rampasan dalam keadaan hilang ataupun rusak, penyebab terjadinya hal tersebut antara lain belum maksimalnya proses pemeliharaan basan dan baran yang di laksanakan oleh pihak Rupbasan.

Penelitian ini dilaksanakan supaya penulis dan masyarakat mengetahui bagaimana proses penanganan Benda Sitaan dan Barang Rampasan Negara di Rupbsan kelas I Makassar Juga mengetahui upaya menyelesaikan masalah yang timbul agar dalam Penanganan Benda Sitaan dan Barang Rampasan Negara di Rupbasan Kelas I Makassar dapat terlaksana sesuai tugas pokok nya, untuh itu dibutuhkan kontribusi yang baik dari berbagai instansi yang terkait diantanya kepolian , Kejaksaan, dan Pengadilan serta Instansi lainnya untuk menyerahkan benda sitaan dan barang rampasan untuk di simpan di Rupbasan agar lebih aman dan terjaga keutuhan dan nilai barang.

\section{METODE}

\section{Lokasi Penelitian}

Penelitian dilakukan di RUPBASAN (Rumah Penyimpanan Benda Sitaan Negara) Makassar,lokasi penelitannya di Jalan Rutan No.2a Kelurahan GunungSari, Kecamatan Rappocini, Kota Makassar, Provinsi Sulawesi Selatan.

\section{Metode Penelitian}

Adapun penelitian merupakan penelitian Hukum Empiris dan pendekatan yang digunakan adalah pendekatan secara kualitatif.

\section{Jenis Data}

Untuk Jenis data yang akan dipakai yaitu :

a. Data yang di peroleh langsung dari hasil wawancara maupun observasi di lapangan yang diistilahkan data primer.

b. Data yang di peroleh dari Peraturan PerundangUndangan ,Internet, buku, literatur serta Sumber lainnya yang dikenal dengan data sekunder .

\section{Metode pengumpulan data}

Adapun metode pengumpulan data Penelian ialah:

a. Melalui Wawancara kepada pihak terkait

Yaitu untuk mendapatkan data dan melakukan Tanya jawab ke pada pihak RUPBASAN dan kejaksaan, dan disimpulkan menjadi sebuah wawancara serta mendapatkan data proses penerimaan sampai pengeluaran basan dan baran sitaan serta permasalah yang yang terjadi selama proses penanganan barang sitaan tersebut.

b. Melalui Studi Pustaka

ialah cara pengumpulan data Sekunder seperti Peraturan Perundang - undangan,dokumentasi dan bahan Pustaka lainya yang sesuai dan relevan.

Metode Analisis Data

Berikut urutan proses menganalisis data yang didapatkan dilapangan yaitu: pengorganisasian , menyusun data dalam pola, kategori dan uraian dasar untuk dapat menemukan suatu subjek yang dirumuskan pada hipotesis kerja seperti yang dicantumkan pada data.

\section{HASIL DAN PEMBAHASAN}

RUPBASAN merupakan singkatan dari Rumah Penyimpanan Benda Sitaan Negara yaitu Tempat menyimpan Benda Sitaan dan Barang Rampasan yang disita oleh negara yang dijadikan sebagai alat/barang bukti untuk proses pengadilan kasus terkait. Umumnya RUPBASAN dibangun disetiap kota provinsi di Indonesia namun jika diperlukan maka cabang dari RUPBASAN diperbolehkan dibangun di kecamatan tertentu yang ditetapkan sesuai dengan kebutuhan. Alat/barang bukti yang disimpan atau dititip di RUPBASAN akan digunakan untuk kebutuhan proses pemeriksaan kasus pidana diantaranya penyelidikan, penuntutan, pemeriksaan pada sidang Pengadilan, termasuk barang yang dinyatakan dirampas oleh Negara berdasarkan keputusan Hakim Persidangan.

RUPBASAN dididrikan atas dasar peraturan menteri kehakiman denagn No : M.05.UM.01.06 pada tahun 1983 yang berisi tentang pengelolaan benda sitaan Negara di RUPBASAN serta peraturan pemerintah nomor 27 tahun 1983 yang berisi tentang pelaksanaan KUHAP serta undang-undang nomor 8 tahun 1981 Tentang Hukum Acara Pidana dan Pancasila.

Berdasarkan pada Keputusan Menteri Kehakiman Republik Indonesia mengenai Organisasi dan tata kerja Rumah Tahanan Negara dan Penyimpanan Benda Sitaan Negara yang tercantum pada nomor :M.04.PR.03 tahun 1985 dengan bunyi bahwa : Rumah Penyimpanan Benda Sitaan Negara ialah unit pelaksana teknis di bidang Penyimpanan Benda Sitaan dan Barang Rampasan Negara 
yang berada di bawah dan bertanggung jawab langsung Kepala Kantor Wilayah Departemen Kehakiman RI.

Kemudian dinyatakan bahwa RUPBASAN mempunyai tugas pokok dan fungsi sebagai berikut :

1. RUPBASAN memiliki tugas pokok yaitu merupakan tempat Penyimpanan Benda Sitaan Negara dan Barang Rampasan Negara.

2. RUPBASAN memiliki empat fungsi,yakni terdiri atas : mengadministrasikan benda sitaan atau barang rampasan yang masuk, memelihara beda sitaan maupun benda rampasan termasuk mutasinya, mengamankan serta mengelola Benda Sitaan dan Barang Rampasan serta melakukaan urusan surat mneyurat dan kearsipan berkas .

Adapun Tujuan dari tersedianya RUPBASAN ialah menjaga dan memelihara keutuhan alat/barang bukti serta nilai dari Benda sitaan ataupun Barang Rampasan Negara. Basan atau Benda Sitaan Negara adalah benda yang bisa bergerak ataupun yang tidak bisa bergerak, benda berwujud atau tidak berwujud yang diambil alih dan kemudian dititip untuk diawasi kemudian digunakan saat proses pembuktian mulai dari penyelidikan, penuntutan sampai ke peradilan.

Sesuai Pasal 39 ayat 1 undang-undang Tahun 1981 tentang KUHAP bahwa golongan yang dikenakan terdiri atas:

1. Benda yang digunakan secara langsung melakuakn tindak pidana

2. Benda yang memang senaja dibuat untuk melakukan tindak pidana.

3. Benda lainnya yang memiliki hubungan dengan tindak pidana yang terjadi

4. Benda yang merupakan milik dari terdakwa/tersangka yang seluruh ataupun sebagian didapat dari tindakan pidana ataupun merupakan hasil dari tindakan pidana.

5. Benda yang digunakan untuk menghalangi penyelidikan tindak pidana yang sedang dijalankan.

6. Sedangkan pengertian dari barang rampasan atau disingkat baran ialah barang bukti yang dirampas oleh Negara karena telah memperoleh kekuatan hukum tetap

Benda sitaan ataupun barang rampasan merupakan bukti yang dapat diperoleh dengan cara penggeledaan, pemeriksaan surat yang dibutuhkan pada saat penyitaan ataupun dari pihak pemilik dengan sukarela kepada pihak yang berwenang. Langkah selanjutnya yang diambil adalah menahannya untuk sementara terhadap benda yang menjadi barang bukti perkara pidana itu kemudian diproses dalam penyelidikan dan penuntutan dalam sidang peradilan.

Bersadarkan hukum acara pidana belanda pasal 134 menyatakan bahwa :'Dengan Penyitaan sesuatu benda diartikan pengambilalihan atau penugasan benda itu guna kepentingan acara pidana”.

Proses penyitaan dilaksanakan oleh pihak penyidik dengan menyertakan surat rekomendasi dari pihak Pengadilan Negeri terkait.
Dalam proses penyitaan dilaksanakan oleh beberapa pihak, diantaranya :

1. Pihak Penyidik berdasarkan perintah penyidikan sesuai Pasal 5 ayat 1 huruf b poin 1 KUHAP

2. Pihak Penyidik sesuai Pasal 7 ayat 1 huruf $d$ KUHAP.

3. Pihak Penyidik pembantu sesuai pasal 11 KUHAP.

Kegiatan Penyitaan dimulai dari hasil pelaporan kepolisian, bersamaan dengan berkas/dokumen pemeriksaan di lokasi TKP, kasus ini juga merupakan bahan laporan dari Penyelidikan kepolisian dan berkas pemeriksaan tersangka ataupun saksi dan keterangan laiinnya yang berhubungan dengan pembuktian kasus pidana di persidang pengadilan.

Penunjukan alat bukti tersebut bertujuan agar alatalat bukti yang diajukan dalam persidangkan harus pula didukung dengan barang bukti yang kuat. Maka proses pembuktian harus dapat meyakinkan Hakim agar membuat keputusan yang tepat / benar serta asas keadilan yang tinggi. Dari pihak penyidik Kepolisian mendapatkan barang bukti dengan melakukan penyitaan,ini adalah proses untuk menyitaan barang bukti dan menyimpan barang tersebut di dalam pengawasaannya.

Berdasarkan Keputusan Direktur Jenderal Pemasyarakatan nomor: E1.35.PK.03.10 Tahun 2002 tentang Barang Rampasan Negara ialah Barang bukti yang sudah mendapatkan kekuatan Hukum untuk dirampas oleh Negara kemudian proses pengeksekusian, diantaranya:

1. Dimusnahkan diantaranya: Ditanam didalam tanah, ditenggelamkan ke dasar laut agar tidak dapat diambil kembali, Dibakar sampai habis dan Diteruskan sampai di RUPBASAN untuk benda sitaan atau barang bukti perkara lain.

2. Dilelang oleh Badan lelang Keuangan.

3. Diberikan ke pihak yang di tunjuk untuk di pergunakan.

4. Dititip/disimpan di RUPBASAN dan dijadikan sebagai alat/ barang bukti Perkara yang lainnya.

Benda yang akan disita dibedakan menjadi :

1. instrumenta delicti yaitu dipergunakan sebagai alat menjalankan kejahatan.

2. corpora delicti yaitu hasil tindak pidana yang dilakukan.

3. Benda tidak memiliki hubungan dengan tindakan pidana naunbisa dijadikan pembuktian

4. Barang bukti pengganti.

Pada Pasal 39 KUHAP menyebutkan bahwa barang terdakwa yang dapat rampas/disita terdiri atas :

1. Tagihan atau barang tersangka/ terdakwa dimana beberapa ataupun seluruhnya merupakan hasil dari tindakan pidana yang sudah dilakukan.

2. Alat bukti yang digunakan untuk melakukan tindakan pidana.

3. Alat bukti yang digunakan menghalangi penyelidikan tindak pidana

4. Alat yang di gunakan menghalangi petugas pada saat terjadinya pengejar tersangka untuk melarikan diri. 
5. Barang yang memang sudah disediakan dari awal untuk melakukan aksi tindak pidana.

6. Benda atau alat bukti lain yang digunakan langsung oleh terdakwa/tersangka untuk melakukan tindakan pidana.

7. Benda karena perkara perdata ataupun masalah pailit sehingga dilakukan penyitaan untuk mempermudah proses penyelidikan sampai pada hasil yang diperoleh dari persidangan.

Untuk memperlancar proses pengelolaan/penanganan basan ataupun baran sehingga prosesnys berjalan sesuai peraturan yang berlaku, kenyataannya merupakan bukan hal yang sepeleh untuk mencapai seperti yang sudah direncanakan sebelumnya. Selain itu,proses penganan basan ataupun baran membutuhkan adanya pengawasan ekstra ketat. Menurut Arifin Abdul Rahman bahwa:

1. pengawasan berarti memastikan semua yang direncanakan sesuai dengan rencana awal yang sudah ditetapkan.

2. pengawasan berarti memastikan semua yang direncanakan berjalan sesuai prinsip yang sudah ditetapkan

3. pengawasan berarti mendeteksi dari kelemahan sampai kendala yang timbul serta melaksanakan pencegahan melakukan kembali kesalahan yang sama.

4. pengawasan berarti memastikan semua berjalan secara efisien dan peningkatan efisiensi pengawasan agar hasil yang diperoleh lebih maksimal

Melalui proses pengawasan ini, pihak Rupbasan Makassar mengetahui batas dimana penyimpangan, kebocoran, pemborosan, penyalahgunaan, penyelewengan, serta masalah yang akan timbul nantinya. Maka bisa disimpulkn definisi dari pengawasan ialah suatu proses melakukan perbandingan antara hasil yang dicapai setelah melakukan pengawasan dengan rencana awal yang sudah dipikirkan sebelumnya.apakah ada perbedaan yang signigfikan atau sebaliknya.

Dengan demikian terlihat adanya korelasi yang erat antara proses pengawasan dengan proses perencanaan sebelumnya, sebab proses pengawasan dimaknai suatu kegiatan untuk mereview kembali semua proses secara terstruktur apakah muncul penyimpangan di dalamnya atau tidak.

Tampak jelas bagaimana pengaruh antara pengawasan dan perencanaan yang sudah kita buat sebelumnya ,perlu adanya suatu pedoman yang digunakan agar bisa berhasil dengan baik. Jika perencanaan tidak disertai dengan pengawasan maka akan menghasilkan munculnya penyelewengan, kebocoran, dan penyimpangan tanpa bisa di antisipasi sebelumnya.

Sama halnya dengan manajemen, Karena tanpa manajemen segala sesuatunya tidak sesuai dengan yang sudah direncanakan. Seperti kasus yang terjadi pada beberapa bidang yang penugasanya tidak terselesaikan dengan baik, laporan penggunaan anggaran molor dari waktu yang ditetapkan serta adanya kegiatan yang tidak sesuai dengan rencana. Begitu pentingnya kegiatan pengawasan di RUPBASAN Makassar agar kinerja yang di hasilkan bisa menjadi tolak ukur hasil proses pengawasan yang dilakukan sesuai rencana.

Proses Pengawasan berfungsi mencegah penyimpangan pelaksanaan tugas sedini mungkin. penganan benda sitaan Negara memiliki fungsi yaitu tumbuhnya integritas pada penangan basan ataupun baran pengawasan bisa berjalan dengan aman, tertib dan lancar sesuai peraturan.

Begitu pentingnya melaksanakan pengawasan agar tercipta kedisiplinan dalam kinerja penanganan benda sitaan di RUPBASAN Makassar.

Wewenang tugas struktur organisasi di Rupbasan adalah :

1. Kepala RUPBASAN adalah penanggung jawab pada proses penanganan basan maupun baran. Serta sebagai pemberikan legitimasi dalam hal pendatanganan surat.contohnya surat ijin pengeluaran barang untuk keperluan lelang, keperluan pemusnahan barang rampasan,dan surat untuk instansi yang terkait.

2. Kepala Subsi Administrasi dan Pemeliharaan bertanggungjawab dalam pelaksanaan secara administrasi mulai penerimaan benda sitaan ataupun barang rampasan sampai pada proses pengeluarannya. Proses ini tersebut dilakukan secara terstruktur mulai dari proses penerimaan,penelitian, penilaian, pendaftaran serta penyimpanan basan dan baran masuk ke Rupbasan Kelas 1 Makassar biasanya di bawah oleh pihak penyidik kepolisian,penuntut dar pihat kejaksaan atau pihak pengadilan dengan sesuai prosedur penerimaan di Rupbasan.

3. Kepala Subsi pengamanan dan pengelolaan yang bertanggungjawab dalam pelaksanakan pengamanan basan dan baran serta pengamanan yang terdapat di Rupbasan Kelas I Makassar. Tugas kontrol piket biasanya yang dilakukan pada malam hari antara pukul 18.00 WITA sampai pukul 07.00 WITA.kegiatan control biasanya di lakukan setiap 2 jam sekali.

Penerimaan dan penelitian basan/baran di RUPBASAN Makassar

RUPBASAN Makassar diberikan kewenangan agar bisa mengelolah basan maupun baran sesuai prosedur karena itu RUPBASAN secara fisik dan administrasi bertanggung jawab untuk semua baran ataupun basan yang dititip ataupun disimpan,dipelihara sera dipertahankan keutuhannya. Berdasarkan bunyi pasal 27 ayat 4 PP nomor 27 tahun 1983 berbunyi :

"Kepala RUPBASAN tidak boleh menerima benda yang harus disimpan untuk keperluan barang bukti dalam pemeriksaan, jika disertai surat penyerahan yang sah, yang dikeluarkan oleh pejabat yang bertanggung jawab secara yuridis atas benda sitaan tersebut"

Untuk itu proses penerimaan Benda sitaan ataupun benda rampasan di RUPBASAN Kelas I Makasssar, 
Petugas penerima Rupbasan harus memeriksa dokumen pendukung dari segi keabsahannya yaitu:

1. Surat dari kejaksaan berupa surat pengantar;

2. Surat tentang perintah untuk melakukan penyitaan dari pihak berwenang;

3. Surat itentang izin melaksanakan penyitaan dari pihak berwenang;

4. Bukti laporan berupa berkas berita acara pada saat penyitaan dari pihak berwenang.

Direktur jenderal pemasyarakatan memberikan petunjuk pelaksanaan serta petunjuk teknis mengenai pengelolaan basan ataupun barandengan prosedur penerimaannya sebagai berikut:

1. Lokasi penerimaan basan/baran dilaksanakan di kantor RUPBASAN Makassar

2. Bagian Petugas penerimaan yang sedang bertugas pada saat itu yang akan melakukan penerimaan basan/baran

3. Surat/dokumen yang dibawa segera diperiksa untuk melengkapi data basan atau baran tersebut sekalianmengklasifikasi jenis baran atau basan tersubut

4. Petugas penerima mengantarkan basan atau baran tersebut untuk dilakukan penelitian.

5. Baran yang berupa tanah, rumah dan lain - lain yang tidak bisa disimpan di RUPBASAN maka adanya tindakan selanjutnya mengecek keberadaan dan kebenaran data yang diterima

6. Mendokumentasikan dan disimpan dalam arsip kantor RUPBASAN.

7. Kegiatan terakhir petugas penerima menyertakan laporan berupa berita acara pada saat pelaksanaan penelitian sesuai dengan hasil penelitian yang diperoleh untuk data dari basan atau baran tersebut.

\section{Proses Penelitian Benda Sitaan}

Proses selanjutnya adalah penelitian basan atau baran dimana benda sitaan dan benda rampasan Negara memiliki tiga kegiatan, yakni: penelitian, pemeriksaan, dan penaksiran. Dalam kegiatan penelitian sasaran kegiatan untuk penelitian difokuskan pada aspek fisik dan kuantitas benda sitaan dan benda rampasan. Seperti pemeriksaan kondisi fisik benda,kemasannya, keadaan segelnya. Selanjutnya proses pemeriksaan difokuskan untuk jumlah,dan pada aspek legalitas kelengkapan data yang mendukung. Intinya berupa pengecekan keaslian berkas dokumen bersamaan diantarkan dengan barang bukti dan saat pihak penyidik menyerahkan basan ataupun baran ke RUPBASAN kelas I Makassar serta untuk perhitungan harga atau nilai suatu benda sitaan atau barang rampasan. contohnya jika basan ataupun baran berupa emas maka untuk mengetahui besarnya nilai karatnya harus disediakan alat ukur dan cairan kimiauntuk mendeteksi deskripsi emas tersbut.

Dalam penelitian benda sitaan dilaksanakan berdasarkan hal sebagai berikut:

1. Menyediakan ruangan khusus untuk dilakukan penelitian tentang basan/baran tersebut.
2. Menjaga benda tersebut tetap utuh agar tidak terjadi kerusakan.

3. Petugas yang melakukan penelian harus memiliki keahlian khusus mengenai jenis dan mutu dari benda sitaan/barang rampasan.

4. Melakukan pemotretan pada basan/baran sebagai kelengkapan administrasi.

5. Apabila di Rupbasan tidak tersedia tenaga ahli untuk penelitian maka dapat memakai tenaga ahli dari luar sesuai permintaan Kepala Rupbasan.

6. Membuat berita acara untuk proses penelitian penelitian

7. Untuk penelitian sampai perhitungan nilai basan dikerjakan oleh tenaga ahli selain dari pihak RUPBASAN atau dari PIHAK luar yang diminta melakukan penelitan maka wajib menandatangani berita acara sebagai bukti dokumen.

Proses pendaftaran basan dan baran di RUPBASAN Makassar

Adapun proses pendaftaran untuk benda sitaan maupun benda rampasan yakni:

1. Pihak Petugas bagian di bagian pendaftaran memeriksa keabsahan dokumen tentang tidakan penyitaan dan berkas penyerahan dokumen berita acara peneitian basan dan baran menyesuaikan dengan barang bukti.

2. Petugas mengisi data pada buku pendaftaran atau register berdasarkantingkatan kasus yang sudah diperiksa.

3. Memberi pelabel basan maupun baran disertakan oleh pengisian secara lengkap dan cermat oelh petugas penelitian.

4. Pengisian data pada label tentang nomor register penerimaan,pihak yang menitip,berita acara,hasil yang diperoleh dari penelitian,nomor pemilik atau tersangka,waktu penyimpanan dan bentuknya seperti apa.

Penyimpanan dan Pemeliharaan Benda Sitaan di RUPBASAN Makassar

Kegiatan pemilihan lokasi tempat penyimpanan dipergunakan untuk menyimpan basan maupun baran harus sesuai spesifikasi basan/barang sitaan, sehingga diperlukan pengaturan sesuai ruang yang mencakup bentuk gudang penyimpanan barang, agar penggunaan ruangan gudang bisa secara efisien, serta pengawasan ruangan ruang gudang bisa maksimal, penyimpanan benda sitaan harus memperhatikan sifat,jenis barang serta keselamatan basan/baran, yaitu aman terhadap pencurian,kebakaran, dan gangguan lain yang mungkin timbul baik disengaja maupun tidak disengaja.

Proses penyimpanan dibutuhkan beberapa aturan saat menyimpan, maupun penentuan tempat menyimpan basan ataupun baran yang disesuaikan dengan kondisi basan dan baran. Adapun syarat penyimpanan adalah sebagai berikut :

1. Letak Lokasinya strategis dan terjangkau akses lalul lintas, dnding gudang terbuat dari tembok, semua ruangan ruangan memiliki plafon, ventilasi cukup 
dan kondisi terang, alat pemadam tersedia, tersedia pintu darurat

2. Penyimpanan baran maupun basan harus ditempat yang layak dan baik.

3. Tersedia nama baran atau basan dalam bentuk label untuk mempermudah dalam proses pencarian barang sitaan ataupun barang rampasan ketika dibutuhkan.

Pemeliharaan Benda Sitaan

Dalam kegiatan Pemeliharaan benda sitaan maupun

barang rampasan perlu penegasan bagaimana syarat,aturan ataupun tata cara agar tercipta kondisi yang diinginkan seperti penyimpanan yang aman, selamat dan keutuhan dari benda sitaan maupun barang rampasan , sehingga selama masa penyimpanan di Rupbasan Kelas 1 Makassar dilaksanakan peningkatan proses pemeliharaan. berdasarkan juknis dirjen Pemasyarakatan tentang pengelolaan benda sitaan. Dimana dijelaskan bahwa pemeliharaan ialah proses kegiatanmengawasi, mengadakan pemeriksaan secara berkala, serta mengadakan pemeliharaan khusus untuk benda sitaan ataupun barang rampasan tertentu tertentu.

Dan proses pemeliharaan benda sitaan ataupun benda rampasan negara dilaksanakan sesuai aturan yang telah ditentukan, yaitu dilaksanakan :

1. Dengan cara berkala, yakni dilaksankan sebanyak dua kali dalam seminggu.

2. Dengan cara darurat, yakni dilaksanakan pada benda sitaaan khusus

3. Dengan mengamankan khususnya basan ataupun baran yang dianggap berbahaya

4. Memasukkan catatan serta Laporan ke instansi yang memiliki tanggung jawab secara yuridis apabila dalam proses pemeliharaan terjadi kerusakan barang sitaan ataupun barang rampasan serta menyusutnya nilai basan

5. Kegiatan basan ataupun baran tersebut dilakukan dengan penuh tanggung jawab.

6. Mengupayakan untuk menuliskan catatan serta memberi nilai dari hasil proses pemeliharaan barang sitaan maupun barang rampasan tersebut.

Adapun Mekanisme pada proses pemeliharaan basan atau baran yaitu:

1. Breakdown maintenance yaitu proses memelihara karena kerusakan mesin Proses pemeliharaan ini dikatakan pemeliharaan tidak terprogram, artinya dilakukan jika mesin tidak dapat digunakan atau telah benar berhenti, atau saat darurat.

2. Proses pemeliharaan yang terprogram, apabila terdeteksi dari awal jadwal peralatan harus diperbaiki atau set-up, jadi dipersiapkan sebelumnya agar mampu dikontrol.

3. Proses pemeliharaan preventif atau pemeliharaan untuk pencegahan.

4. Perbaikan secara berkala agar terdeteksi kondisi mesin yang bisa menyebabkan kerusakan secara tiba-tiba atau breakdown. agar kita bisa memprediksi kemungkinan kerusakan dengan cepat dan terencana atau adanya kerusakan pada bagaian tertentu mesin.
Pemeliharaan terdapat bebera jenis yakni :

1. Pemeliharaan secara rutin yang bersifat rutin harian dilaksanakan agar mesin dan peralatan bisa berfungsi dengan baik, dan terkadang tidak butuh perbaikan ataupun penggantian suku cadang.

2. Pemeliharaan secara besar atau major Maintenance yang terjadwal dan dilaksanakan secara periode, agar mengembalikan kondisi mesin atau peralatan menjadi seperti semula agar tercapai kapasitas semula (original design capacity) pada operating condition. butuh waktu cukup panjang, kadang lamanya sampai berbulan-bulan.

3. Pemeliharaan Prediktif atau Predictive Maintenance yaitu Memakai teknik pengukuran modern serta teknik proses gejala. Pemeliharaan prediktif ini mendiagnosa bagaiman keadaan mesin atau peralatan yang sementara beroperasi juga dapat menentukan waktu pelaksanaan pemeliharaan mesin/pralatan selanjutnya.

Peyelamatan dan pengamanan basan maupun baran di RUPBASAN Makassar

Pada kegiatan pengamanan serta pnyelamatan basan maupun baran memiliki tujuan utama seperti pada PP nomor 27 tahun1983 pasal 27 ayat 3 tentang Tujuan utama disimpannya benda sitaan di Rumah penyimpanan barang sitaan Negara adalah untuk menjamin keselamatan dan keamanannya. Kegiatan pengamanan serta menyelamatkan basan adalah untuk mempertahankan kondisi basan maupun barang rampasan maupun nilai sehingga dalam prosesnya tugas menyelamatkan dilakukan oleh para staf bagian pengamanan, yang terdiri dari :

1. Kepala kesatuan pengamanan.

2. Staf kesatuan pengamanan.

3. Masing-masing Kepala Regu Jaga yaitu minimal 4 orang.

4. Anggota Regu Jaga.

Peraturan menteri kehakiman RI nomor: M.05.UM.01.06 tahun 1983, maka proses pengeluaran, yakni :

1. Pengeluaran basan ataupun baran yang akan digunakan untuk keperluan Penyidikan/Penuntutan.

2. Mengeluarkan basan atau baran yang akan digunakan untuk dijadikan alat/barang pada proses Pengadilan, hal ini tercantum pada pasal 46 ayat 1 .

3. Pasal 46 ayat 2 tentang Pengeluaran Benda Sitaan Negara merupakan suatu proses, yakni:

a. Benda sitaan atau basan akan dikembalikan ke pihak pemilik ataupun pihak yang berhak disebut dalam vonis atau putusan hakim;

b. Benda sitaan akan Dirampas untuk negara, selanjutnya akan diberikan tindakan

c. Benda sitaan dirampas untuk negara yang kemudian diberikan kepada negara melalui instansi/lembaga/badan tertentu.

d. Benda sitaan dirampas untuk negara guna dimusnahkan agar tidak dapat dipakai kembali. 
e. Benda sitaan dirampas dan masih disimpan karena masih dibutuhkan.

\section{Pelaporan Pengelolaan Benda Sitaan}

Kegiatan pelaporan penangan basan maupun baran harus lengkap baik data adminsitrasi maupun pemantauan tugas pengelolaan benda sitaan dibutuhkan data informasi yang kuat. Setiap proses dilaporkan ke pejabat berweang dengan terstruktur misalnya setiap hari, minggu, bulan atauun tahun.. Dan apabila telah terjadi peristiwa atau kejadian luar biasa maka pengiriman laporannya dilaksanakann segera mungkin, yaitu pada kesempatan awal setelah kejadian luar biasa tersebut. Dan untuk jenis laporannya, yaitu :

1. Laporan penaganan basan maupun baran.

2. Laporan jika memiliki data tentang mutasi basan atapun baran.

Wawancara dari pihak Rupbasan

Dari hasil wawancara Dari pihak Rupbasan Kelas 1 Makassar bahwa di RUPBASAN tersimpan benda sitaan/barang rampasan Seperti, mobil,motor, eskavator, alat cetak konveksi, Laptop,komputer, kulkas,alat kecantikan, kosmetik tanpa izin edar, meja, kursi,lemari,alat rumah tangga,kayu,tabung gas, dan lainlain,masuknya barang sitaan ini dikarenakan terjadinya beberapa kasus pidana seperti: penipuan, penggelapan, lakalantas, Penjambretan/pencurian, dan sebagainya. Barang sitaaan yang dititipkan paling banyak benda sitaan yang bersifat umum, yang disimpan sesuai dengan klasifikasi gudang tersebut namun barang berharga tidak pernah dititip di RUPBASAN padahal RUPBASAN memiliki gudang khusus atau gudang barang berharga.

Sarana dan prasarana di Rupbasan Makassar masih tergolong belum mencukupi, hanya terdiri dari 13 gudang dan sebagian besar area dalam kantor Rupbasan masih terbuka untuk penyimpanan kendaraan atau barangbarang besar., serta masih ada barang sitaan yang bersifat berharga yang tidak titip di rupbasan,karena pihak Kejaksaan masih menyimpan barang sitaan tersebut di kantor Kejakaan atau gudang penyimpanan yang terdapat di kantor Kejasaan.

Ada beberapa basan maupun baran yang belum di keluarkan dari RUPBASAN tanpa adanya konfirmasi yang jelas,kurangnya informasi yang resmi dari instansi terkait tentang pengklasifikasian atau mutasi antara basan maupun baran

Proses penanganan basan maupun baran adalah proses kegiatan yang tidak bisa dipisahkan, tahapan yang wajib dipenuhi yaitu : berkas yang mendukung serta benda sitaan diserahkan kepada petugas di bagian pendaftaran penyimpanan harus sesuai, selanjutnya barang diklasifikasi sesuai jenisnya berharga, benda berbahaya, ataupun umum,kemudian diamankan pada gudang sesuai kategorinya, pihak Rupbasan melakukan proses pendaftaran benda sitaan di buku catatn barang yang masuk di RUPBASAN Makasaar,dan untuk proses pemeliharaan, yang harus diperhatikan yakni dalam proses pemeliharaan dilakukan sebanyak dua kali dalam seminggu. Dengan membersihkan benda sitaan ataupun barang rampasan dari debu, dan untuk benda sitaan berupa benda bergerak, selalu memperhatikan bagian luar dan juga bagian mesin,misalnya jika bensin habis maka segera diisi tidak dibiarkan tangki kosong, termasuk selalu memeriksa oli dari kendaraan tersebut.

Pada proses Mutasi adalah proses memindahkan benda sitaan maupun barang rampasan,secara fisik dan yuridis, yaitu saat benda sitaan mengalami perubahan status ,misalnya dari proses penyidikan berubah menjadi proses penuntutan, jadi data pada buku register otomatis mengalami perubahan menjadi proses pemeriksaan. Dan pengeluaran benda sitaan maupun barang rampasan negara, yakni butuh perhatian berupa berkas terkait / pengadilan, selanjutnya laporan dalam betuk berita acara proses pengeluaran benda sitaan dari pihak pengadilan, dan data lainnya yaitu berkas berupa bukti identitas dari pihak yang menerima barang tersebut .proses akhir ialah prosses pelaporan yang merupakan proses peremajaan yang berkaitan dengan RUPBASAN dan basan ataupun baran secara keseluruhan, kemudian disatukan dalam satu laporan secara terstruktur.

Proses pemeliharaan benda sitaan dan barang rampasan dilakukan pihak subsi administrasi dan pemeliharaan, proses ini biasa dilakukan setiap 1 minggu yaitu 2 kali dalam seminggu tepatnya hari selasa dan jumat hpetugas pemeliharaan di bagi menjadi 2 bagian keperluan pemeliharaan.proses pemelihataan biasanya yaitu mulai dari pembersihan benda-benda sitaan ada yang dilap kususnya perabotan rumah tangga,barangbarang elektronik,perabotan kantor hasil sitaan, meja kursi kantor sitaan, setelah di lap bersih selanjutnya di tutup dengan pelastik bening yang biasanya di gunakan untuk melapisi taplak meja makan, phak Rupbasan menyiapkan plastik tersebut sekitar 5 rol besar atau sesuai dengan barang-barang yang akan di tutupi,barang-barang seperti besin jenset,mesin kapal,pupuk untuk bom ikan, sertados-dos yang berisi pulpen hasil sitaan biasanya di tutupi oleh terpal/tenda yang ukurannya sesuai agar barang-barang tersebut tidak gampang rusak, namun khusus pupuk bom ikan di tempatkan di gudang tersendiri,tidak di gabung dengan benda-benda sitaan yang lain agar tidak merjadi kebakaran atau memicu ledakan, untuk kendaraan seperti motor dan mobil biasanya di rawat dengan cara diisi bensin atau bbm serta di ganti olinya secara berkala dan di nyalakan agar harga barang tidak menurun drastis,jika barang tersebut tidak bisa nyala maka akan di pindahkan ke gudang lain untuk proses perawatan lebuh lanjut, setelah di cek mesinnya dan dinyalakan selanjutnya kendaraan tersebut di cuci untuk menghilangakan debu dan kotoran,setelah di bersihkan dan dicuci kendaraan tersebut di kembalikan ke gudangnya,untuk perawatan kayu-kayu hasil sitaan disimpan di area Rupbasan yang tidak tertutup oleh atap ,agar kayu tersebut bisa tahan panas,hujan dan rayap biasanya kayu tersebut disemprot dengan cairan anti rayap dan setelah itu ditutup dengan terpal besar supaya tidak terkena panas matahari dan hujan secara langsung. Untuk BBM dan tabung gas di simpan di pinggaran gung 
yang terdapat atapnya dan di tutup lagi oleh terpal agar bisa mengurangi penguapan dari $\mathrm{BBM}$ tersebut dan tabung gas juga tidak mudah rusak. Kegiatan perawatan basan dan baran di kantor Rupbasan biasanya di backup oleh pihak petugas pengamanan. Serta setiap bulan atau setiap 3 bulan sekali kasubsi pengelolaan dan administrasi bersama kasubsi pengamanan dan pengelolaan melaksanakan control dan pengecekan barang sitaan dan barang rampasan atas instruksi atau perintah langsung dari kepala Rupbasan. Adapun masalah yang dihadapi pada proses penanganan basan maupun baran di RUPBASAN Kelas 1 Makassar yakni RUPBASAN Makassar belum memiliki tenaga ahli dalam benda-benda tertentu, gedung yang belum mencukupi,selanjutnya masalah sarana prasarana, dan dari pihak kejaksaan belum menitipkan basan maupun baran secara keseluruhan Kelas I Makassar, kemudian benda sitaan yang ada di RUPBASAN beberapa merupakan basan maupun baran yang sudah lebih 8 tahun, dan masih ada juga basan ataupun baran yang sudah mendapat keputusan pengadilan atau kekuatan hukum tetapi belum ada tindakan eksekusi dari pihak berwenang.

Upaya yang dilakukan oleh pihak Rupbasan adalah mengkoordinasikan kepada intansi lain dan mensosialisasikan bahwa rupbasan adalah tempat penitipan benda sitaan negara, kemudian melakukan koordinasi untuk segera melakukan eksekusi pada benda sitaan, dan untuk gedung yang terbatas maka memanfaatkan ruang yang masih kosong walaupun kadang tidak sesuai.

Dan jika ada benda sitaan ataupun barang rampasan yang hilang/rusak maka Kepala Rupbasan wajib bertanggung jawab, akan tetapi tetap melaksanakan penyelidikan mulai dari petugas yang sedang melakukan tugas penjagaan, jika kejadian ini merupakan keteledoran pada saat bertugas maka kehilangan ini menjadi tanggung jawab dari bagian pengamanan basan maupun baran pada saat petugas yang berjaga. Proses memusnahkan basan/baran yang dinyatakan akan di rampas oleh Negara bukanlah wewenang pihak Rupbasan, tapi wewenang kejaksaan. Pihak Rupbasan sekedar menghadiri proses eksekusi benda sitaan ataupun benda rampasan tersebut. Rupbasan tidak mengetahui informasi apapun Benda sitaan yang dititip di luar karena bukan kewenangannya. Pihak Rupbasan cuma berfokus untuk menjaga keutuhan dan nilai dari basan ataupun barang yang tersimpan di dalam RUPBASAN Makassar.

\section{Wawancara dari pihak Kejaksaan}

Hasil wawancara dengan pihak kejaksaan mengenai adanya basan maupun baran yang dipegang sendiri oleh pihak kejaksaan dan tidak disimpan pada Rumah Penyimpanan Benda sitaan Negara (RUPBASAN) Makassar yaitu karena mereka beralasan tersedia tempat penyimpanan basan/baran yang berukuran kecil namun berharga serta barang tertentu, pihak kejaksaan berasumsi bahwa mereka menyimpan barang tersebut untuk memudahkan pengeluaran barang bukti ketika diperlukan dalam persidangan,sehingga mereka menyimpannya sendiri, pihak Kejaksaan juga mengatakan bahwa mereka mempunyai tempat penyimpanan tersendiri di karenakan tidak semua kota kabupaten di Indonesia yang memiliki kantor Rupbasan sehingga itu yang menjadi acuan bagi pihak Kejaksaan memiliki tempat penyimpanan sendiri . Namun pada saat ditanyakan mengapa masih belum menitipkan semua benda sitaan ke pihak Rupbasan Kelas I Makassar padahal di kota Makassar maupun kota besar lainnya juga memiliki Rupbasan,pihak Kejaksaan mengatakan bahwa pihak Rupbasan terlalu ribet di karenakan pihak Rupbasan jika pihak Kejaksaan ingin mengeluarkan benda sitaan untuk persidaan pihak kejaksaan harus mengajukan atau mengirim surat pengeluaran 1 hari sebelum persidangan, itu yang membuat prosesnya terlalu lama,dan harus mengikuti aturan atau proses yang berlaku,contohnya surat-surat pengeluaran pinjam pakai untuk persidangan. Pihak kejaksaan mengatakan bahwa jika pihak Rupbasan mau menyederhanakan proses pengambilan basan dan baran sitan untuk keperluan persidangan mungkin pihak kejaksaan akan menyimpan basan dan baran sitaan yang kecil- kecil ataupun yang berharga ke kantor Rupbasan. Serta pihak Kejaksaan mengatakan jika pihak Rupbasan mau mengeluarakan basan dan baran sitaan yang akan di kembalikan ke pemiiliknya tanpa ada surat putusan Pengadilan maka pihak kejaksaan akan berusaha mengeluarkan benda sitaan tersebut secepatnya dari kantor Rupbasan. Agar jika terjadi mutasi jaksa yang menangani suatu kasus bisa mengeluarkan barang sitaan tersebut sebelum jaksa tersebut pindah tugas. Pada saat ditanya tentang Ada beberapa barang sitaan yang sudah lama tersimpan di Rupbasan tanpa ada status yang jelas sehingga barang tersebut belum bisa di keluarkan sampai saat ini padahal sudah dititipkan kurang lebih 8 tahun. Menurut pihak kejaksaan karena kurangnya proses pengadministrasian dan ada beberapa Jaksa yang menangani kasus barang tersebut pindah tugas sehingga putusan pengadilan untuk barang sitaan ini, tidak di ketahui statusnya dikarenakan berkasnya tercecer.

Pada saat di tanyakan bagaimana kelanjutan untuk pengeluaran benda sitaan yang sudah lama tersimpan di Rupbasan hingga lebih 8 tahun,dari pihak kejaksaan akan mencari kembali berkas - berkas tersebut dan pihak Kejaksaan meminta agar pihak dari Rupbasan juga mengecek hasil dari putusan basan/baran tersebut di pengadilan , akan tetapi langkah tersebut bukanlah merupakan tugas pokok kerja dari Rupbasan, sehingga pihak Rupbasan tidak bisa mengeceknya begitu saja hasil putusan dari barang - barang sitaan tersebut di Pengadilan.

\section{KESIMPULAN DAN SARAN}

Berdasarkan keputusan direktur jendral
pemasyarakatan tentang HAM mengharapkan
pelaksanaan penanganan basan maupun baran sesuai
dengan prosedural yang sudah ditetapkan dimulai dengan
memperkenalkan tentang RUPBASAN kepada semua


pihak instansi terkait misalnya: kejaksaan, kepolisian, pengadilan negeri dan bagaimana peranan penting dari keberadaan RUPBASAN dalam hal penyitaan basan/baran untuk tindakan pidana. Adapun penanganan basan dan baran di RUPBASAN Kelas I Makassar (rumah penyimpanan benda sitaan Negara kelas 1 Makassar), yaitu: Penerimaan dan registrasi, basan barang akan di teliti dan di nilai oleh tim dan dicatat dalam buku registrasi untuk administrasi dan dokumentasi,klasifikasi dan penempatan, pemeliharaan basan baran untuk menjaga nilai ekonomis barang sitaan, penghapusan jika terjadi kerusakan,pelaporan yang dilakukan kepada kepala Rupbasan baik tulisan maupun lisan. Upaya yang dilakukan untuk menyelesaikan kendala baik internal maupun eksternal yang terjadi selama penanganan basan dan baran yaitu Mengatasi Kendala internal dan Mengatasi Kendala eksternal.

\section{DAFTAR PUSTAKA}

Keputusan Direktur Jenderal Pemasyarakatan Departemen Kehakiman RI No.E1.35.PK.03.10 tahun 2002 tentang petunjuk pelaksanaan dan petunjuk teknis Pengelolaan Benda Sitaan Negara dan Barang Rampasan Negara di Rumah Penyimpanan Benda Sitaan Negara.

Keputusan Menteri Kehakiman RI No.M.05.UM.01.06 tahun 1983 tentang Pengelolaan Benda Sitaan Negara dan Barang Rampasan Negara di Rumah Penyimpanan Benda Sitaan Negara.

Lexy J.Moleong, 2012, Metodologi Penelitian Kualitatif, Remaja Rosdakarya, Bandung.

Nur, M., Nurkaidah, N., \& Nonci, N. (2020). Gaya Kepemimpinan Dan Sumber Daya Manusia Terhadap Kinerja Pegawai Pada Kantor Sekretariat Daerah Kabupaten Majene. Jurnal Paradigma Administrasi Negara, 2(1), 24-31.

Peraturan Menteri Hukum dan HAM nomor 16 tahun 2014 tentang tata cara Pengelolaan Benda Sitaan Negara dan Barang Rampasan Negara pada Rumah Penyimpanan Benda Sitaan Negara pada pasal 19.

Peraturan pemerintah indonesia no. 27 tahun 1983

Peraturan Perundang-Undangan

Undang-undang dasar negara republik indonesia tahun 1945.

Undang-undang hukum acara pidana

Undang-undang no.8 tahun 1981 tentang hukum acara pidana.

Vivtor M Situmorang dan jusuf juhrif, 1995, Aspek Hukum Pengawasan Melekat, PT. Rineka Cipta. Hal : 23, Jakarta 